\title{
ANALISIS PERLAKUAN AKUNTANSI PERALATAN KANTOR DAN AKTIVA TETAP PADA PT. ASTRA SEDAYA FINANCE
}

\author{
Andika Prianto Maatuil ${ }^{1}$, Lintje. Kalangi ${ }^{2}$, Stanley Kho Walandow ${ }^{3}$ \\ 1,2,3 Jurusan Akuntansi, Fakultas Ekonomi dan Bisnis, Universitas Sam Ratulangi, Jl. Kampus Bahu, Manado, \\ 95115, Indonesia \\ E-mail : Avengerstrong01@gmail.com
}

\begin{abstract}
Business world is growing rapidly now requires every company or business entity to be more active in berkompetitif and continue to strive to achieve goals that have been set. The main goal of the company is to create maximum profit to increase the company's growth. Fixed assets are one of the main parts of the company's large and depreciated assets in an accounting period. The objective of this research is to know the accounting treatment of fixed assets in compliance with PSAK No. 16 Year 2015 at PT. Astra Sedaya Finance Manado. The type of research that is done is descriptive research. Based on the results of research conducted, the company set the acquisition price for fixed assets sometimes does not occur uniformity for the acquisition price of fixed assets, the management company has never done or acknowledge the decline and write-off of fixed assets while the method of depreciation is done every year against all types of assets using straight-line depreciation method consistently each year by applying the straight-line method and not deviating from generally accepted accounting standards and any purchase of fixed assets for the operations of the company are recorded at historical cost as the basis for measuring its fixed assets.
\end{abstract}

Keywords : Depreciation, Fixed

\section{PENDAHULUAN}

Dunia usaha yang sedang berkembang pesat saat ini menuntut setiap perusahaan atau badan usaha untuk lebih giat dalam berkompetitif dan terus berupaya mencapai tujuan yang telah di tetapkan. Bagi Negara-negara sedang berkembang, perusahaan pembiayaan masih memiliki prospek yang baik hal ini dapat dilihat dengan tumbuh pesatnya perusahaanperusahaan pembiayaan kususnya di Indonesia, karena selain menyediakan barang yang dibutukan konsumen, cara pembayaran lebih ringan yaitu dengan sistem angsuran. Perusahaan pembiayaan merupakan lembaga keuangan non bank yang keberadaanya sangat penting, sebagai jasa alternative.

Tujuan utama perusahaan adalah menciptakan laba yang maksimum untuk meningkatkan pertumbuhan perusahaan, dalam mencapai tujuan tersebut. Masing-masing perusahaan berusaha untuk mempertahankan dan meningkatkan kelangsungan hidup perusahaan. Apalagi di era pasar bebas ini, dimana perangkat teknologi dan modernisasi menjadi bulan-bulanan setiap orang, dicari dan di kejar untuk mencapai kemajuan paling canggih. Persaingan ini dapat terjadi antara beberapa perusahaan yang sejenis mapun tidak sejenis. Pemberi jasa finansial (selain bank) kepada masyarakat yang membutukan. Sebagai mana halnya bank, perusahaan jasa non bank dalam hal ini perusahaan pembiayaan memiliki resiko usaha terutama Interest rate risk (resiko tingkat bunga), credit risk (resiko piutang macet), liquidity risk (resiko likuiditas). Berbagai cara ditempuh pihak manajemen untuk meningkatkan volume penjualan. Mulai dari variasi produk, pemberian hadiah dan potongan harga, sampai dengan penjualan secara kredit. Perusahaan menyadari bahwa persaingan yang sangat ketat mengharuskan perusahaan untuk terus bertahan dan mampu menghasilkan laba. Tedy (2012). 
Aktiva tetap dapat diperoleh dengan beberapa cara seperti membeli secara tunai, membeli secara kredit atau angsuran, pertukaran, penerbitan surat berharga, dibangun sendiri, sewa guna usaha atau leasing dan donasi, cara perolehan aktiva tetap yang digunakan di dalam perusahaan, baik yang baru dipakai maupun yang utama memerluka biaya perawatan dan pemeliharaan agar manfaat aktiva tetap tersebut sesuai dengan perencanaan, oleh sebab itu harus diadakan penyusutan harta tetap sesuai dengan umurnya dan masa manfaatnya. Dalam menghitung besarnya beban penyusutan yang dapat dibebankan oleh suatu perusahaan dalam suatu periode akuntansi, perusahaan dapat menggunakan metode-metode penyusutan berdasarkan ketentuan standar akuntansi keuangan yang berlaku secara umum dan digunakan secara konsisten sehingga laporan keuangan yang disajikan adalah wajar.

Aktiva tetap merupakan salah satu dari beberapa syarat yang dapat mendukung keberhasilan usaha dari perusahaan. Dengan aktiva tetap yang memadai maka kelancaran usaha dan aktivitas operasional dari suatu perusahaan dapat berjalan dengan baik. Sebaliknya, tanpa aktiva tetap yang memadai maka aktivitas perusahaan akan terganggu sehingga akan berpengaruh terhadap kinerja perusahaan tersebut. Jadi secara umum dapat dikatakan bahwa aktiva tetap merupakan harta milik perusahaan yang material dan diperoleh bukan dengan tujuan diperjual belikan melainkan digunakan untuk kegiatan operasional perusahaan dan memiliki masa manfaat lebih dari satu tahun atau satu periode.

PT Astra Sedaya Finance (ASF) merupakan perusahaan pembiayaan otomotif terbesar di Indonesia. Kemampuan meningkatkan tingkat pertumbuhan pembiayaan konsumen yang lebih tinggi dari industri, mendorong pangsa pembiayaan konsumen ASF terhadap nasional terus tumbuh. Perolehan pangsa pasar yang mencapai sekitar 9,4\% di tahun 1999 terus mengalami kenaikan hingga mencapai $13,2 \%$ terhadap industri perusahaan pembiayaan konsumen non bank di bulan September 2004.Sesuai dengan Peraturan Otoritas Jasa Keuangan No. 29/POJK.05/2015 PT. Astra Sedaya Finance melakukan perluasan usaha di bidang Pembiayaan Investasi, Pembiayaan Modal Kerja, Pembiayaan Multiguna dan Sewa Operasi (Operating Lease), baik dengan skema konvensional maupun syariah. PT Astra Sedaya Finance yang merupakan cikal bakal ACC berdiri pada 15 Juli 1982 dengan nama PT Rahardja Sedaya, didirikan guna mendukung bisnis otomotif kelompok Astra.

Berdasarkan survey awal yang dilakukan didapati bahwa didalam perlakuan akuntansi aktiva tetap PT. Astra Sedaya Finance Di Manado. Pada pencatatan atas beberapa transaksi pembelian inventaris kantor yang dibeli pihak manajemen perusahaan didapati terdapat ketidak tepatan dalam menentukan besarnya harga perolehan aktiva tetap. Dari uraian singkat diatas, maka perlu dianalisis mengenai perlakuan akuntansi aktiva tetap yang diterapkan PT. Astra Sedaya Finance dan membandingkannya dengan PSAK No. 16 Tahun 2015.

\section{TINJAUAN PUSTAKA}

\subsection{Konsep Akuntansi}

Akuntansi juga sering menyebut accounting adalah merupakan bahasa bisnis yang dapat memberikan informasi tentan g kondisi bisnis dan hasil usahanya pada suatu waktu atau periode tertentu. (Harahap, 2013: 2) menyatakan akuntansi adalah sistem informasi dan pengukuran yang relevan, dapat diandalkan, dan dapat dibandingkan tentang kegiatan bisnis oraganisasi. (Wild, Shaw \& Chiappetta, 2014: 3).

\subsection{Konsep Akuntansi Keuangan}

Akuntansi keuangan berhubungan dengan masalah pencatatan transaksi untuk suatu perusahaan atau organisasi dan penyusunan berbagai laporan berkala dari hasil pencatatan. Pontoh (2013: 2). Sedangkan dalam Standar Akuntansi Keuangan dijelaskan tentang tujuan laporan keuangan yang isinya tujuan laporan keuangan adalah menyediakan informasi yang menyangkut posisi keuangan, kinerja, serta perubahan posisi keuangan suatu perusahaan, 
yang bermanfaat bagi sejumlah besar pemakai dalam pengambilan keputusan ekonomi. (Hery 2013: 12).

\subsection{Konsep Laporan Keuangan}

Menurut PSAK 1, (2015: 1.3) laporan keuangan adalah suatu penyajian terstruktur dari posisi keuangan dan kinerja keuangan suatu entitas. Pengertian laporan keuangan menurut Munawir, (2012: 5) adalah dua daftar yang disusun oleh akuntan pada akhir periode untuk suatu perusahaan. Kedua daftar itu adalah daftar neraca atau daftar posisi keuangan dan daftar pendapatan atau daftar rugi-laba. Menurut Kasmir, (2013: 7) Laporan keuangan adalah laporan yang menunjukkan kondisi keuangan perusahaan pada saat ini atau dalam suatu periode tertentu. Menurut Hanafi, (2012: 49) Laporan keuangan merupakan salah satu sumber informasi yang penting disamping informasi lain seperti informasi industri, kondisi perekonomian, pangsa pasar perusahaan, kualitas manajemen dan lainnya. Sedangkan Menurut Harahap, (2013: 105) laporan keuangan menggambarkan kondisi keuangan dan hasil usaha suatu perusahaan pada saat tertentu atau jangka waktu tertentu.

\subsection{Konsep Aktiva Tetap}

(Surya, Raja, 2012: 149). Aset tetap (fixed asset) adalah aset yang bersifat jangka panjang atau secara relatif memiliki sifat permanen serta dapat digunakan dalam jangka panjang. Aset ini digunakan oleh perusahaan dan tidak dijual sebagai bagian dari kegiatan oprasional. (Reeve,Weren \& Duchac, 2012:) Menurut Epi, (2013: 15) Aktiva atau harta (assets) dapat di bedakan atas aktiva lancar (current assets) dan aktiva tetap (fixed assets)

1. Aktiva lancar (current assets), merupakan aktiva yang dapat diubah menjadi uang, dijual, atau dipakai dalam jangka waktu satu periode akuntansi (biasanya satu tahun)

2. Aktiva tetap (fixed assets), yaitu aktiva yang memiliki manfaat ekonomis lebih dari satu tahun.

\subsection{Pengertian Aktiva Tetap Menurut PSAK No.16 (Tahun 2015)}

Pernyataan Standar Akuntansi Keuangan Nomor 16 Tahun. 2015 adalah standar akuntansi yang dikeluarkan oleh Ikatan Akuntansi Indonesia yang mengatur tentang perlakuan akuntansi aktiva tetap. Pernyataan-pernyataan dalam PSAK No.16 Tahun 2015 harus diterapkan dalam perlakuan akuntansi aktiva tetap kecuali ada pernyataan lain yang menetapkan atau mengizinkan perlakuan akuntansi yang berbeda dengan standar ini.

Di dalam PSAK No.16 (tahun 2015) yang dimaksud dengan aktiva tetap adalah aktiva berwujud yang :

a. Dimiliki untuk digunakan dalam produksi atau penyediaan barang dan jasa untuk durentalkan kepada pihak lain, atau untuk tujuan administratif

b. Diharapkan untuk digunakan selama lebih dari satu periode.

\subsection{Pengakuan Harga Perolehan Aktiva Tetap} berikut :

Aktiva tetap dapat diperoleh melalui beberapa cara. Diantaranya adalah sebagai

1. Pembelian tunai

Harga perolehan aktiva tetap yang dibeli dengan tunai meliputi semua pengeluaran dan pembayaran yang terjadi untuk mendapatkan aktiva tetap tersebut sampai pada kondisi siap pakai untuk digunakan.

Aktiva yang diperoleh dengan cara pembelian tunai dicatat sebesar uang yang dikeluarkan, yaitu terdiri dari harga belinya termasuk bea import dan PPN masukan, atau biaya pembangunan ditambah biaya-biaya yang dapat didistribusikan secara langsung seperti biaya angkut, biaya pemasangan, biaya balik nama, biaya simpan dan bongkar muat, juga biaya professional seperti arsitek. Brikut contoh jurnalnya :

2. Pembelian secara kredit 
Pembelian secara kredit mengakibatkan adanya penangguan pembayaran. Hutang biasanya dibuktikan dengan wesel, surat berharga, hutang hipotik. Hutang ini dibayar dengan beberapa kali angsuran di tambah dengan pembayaran bunganya.Operating Lease . Pembayaran sewa dalam sewa operasi diakui sebagai beban dengan dasar garis lurus (straight-line basis) selama masa sewa kecuali terdapat dasar sistematis lain yang dapat lebih mencerminkan pola waktu dari manfaat aset yang dinikmati pengguna. Sewa operasi, pembayaran sewa (tidak termasuk biaya jasa seperti biaya asuransi.dan pemeliharaan) diakui sebagai beban dengan dasar garis lurus kecuali terdapat dasar sistematis lain yang lebih mencerminkan pola waktu dari manfaat yang dinikmati pengguna, walaupun pembayaran dilakukan tidak atas dasar tersebut.

3. Pembelian dengan surat berharga

Aktiva tetap yang diperoleh dengan mengeluarkan surat-surat barharga berupa saham atau obligasi dicatat sebesar harga pasar atau obligasi pada saat perolehan aktiva tersebut. Selisih antar harga pasar saham/obligasi tersebut.

\section{Diterima dari sumbangan}

Perusahaan dapat memperoleh aktiva tetap dari sumbagan atau bantuan pemerinatah atau badan-badan lain. Transaksi ini disebut dengan nonrespirocal transfer atau transfer yang tidak mengeluarkan umpan balik.

5. Dibanguan sendiri

Tedapat beberapa factor yang memengaruhi perusahaan dalam memenuhi kebutuhan aktiva tetap dengan membangunnya sendiri, antara lain:
a) Menekan biaya
b) Kegiatan untuk mendapatkan mutu yang lebih baik
c) Memanfaatkan fasilitas yang menganggur
d) Aktiva tetap yang dibutuhkan tidak dijual dipasaran

6. Pertukaran atau tukar tambah

Menurut PSAK 16 Tahun 2015 Par. 24 menyatakan bahwa untuk pertukaran aktiva tetap, biaya perolehan diukur pada nilai wajar kecuali.

a) transaksi pertukaran tidak memiliki subtansi komersial

b) nilai wajar dari aktiva yang diterima dan diserahkan tidak dapat diukur secara andal.

\subsection{Pengukuran Awal Ketika Aset Tersebut Diperoleh}

Aset tetap yang memenuhi kualifikasi untuk dikategorikan sebagai aset tetap pada awalnya diukur sebesar biaya perolehan. Biaya perolehan aset adalah jumlah biaya yang dikeluarkan oleh entitas dan diperlukan untuk menyiapkan aset tetap tersebut agar dapat digunakan sebagaimana mestinya sebuah aset tetap. Biaya perolehan aset tetap menurut PSAK Nomor 16 Revisi Tahun 2015 meliputi:

1. biaya perolehan, termasuk bea impor dan pajak pembelian yang tidak boleh dikreditkan setelah dikurangi dengan diskon pembelian dan potongan lain

2. biaya-biaya yang dapat diatribusikan secara langsung untuk membawa aset ke lokasi dan kondisi yang diinginkan agar aset sesuai dengan keinginan dan maksud manajemen. Contoh biaya yang dapat diatribusikan secara langsung adalah:

1. biaya penyiapan lahan untuk pabrik

2. biaya penanganan dan penyerahan awal

3. biaya perakitan dan instalasi

4. biaya pengujian aset apakah dapat beroperasi dengan baik, setelah dikurangi hasil penjualan dari produk yang dihasilkan atas pengujian tersebut

5. komisi profesional

3. estimasi biaya pembongkaran dan pemindahan aset tetap dan restorasi lokasi aset 


\subsection{Penyusutan dan Metode Penyusutan Aktiva Tetp}

Definisi penyusutan menurut PSAK No. 17 (2015) adalah alokasi jumlah suatu aktiva yang dapat disusutkan sepanjang masa manfaat yang diestimasi. Penyusutan untuk periode akuntansi dibebankan ke pendapatan baik secara langsung maupun tidak langsung.

Aktiva yang dapat disusutkan adalah aktiva yang:

a. Diharapkan untuk digunakan selama lebih dari satu periode akuntansi;

b. Memiliki suatu masa manfaat yang terbatas; dan

c. Ditahan oleh suatu perusahaan untuk digunakan dalam produksi atau memasok barang dan jasa, untuk disewakan, atau untuk tujuan administrasi.

Ikatan akuntansi Indonesia (PSAK 2015: 16.11) mengungkapkan bahwa metode penyusutan dapat dilakukan dengan berbagai metode yang dapat dikelompokkan menurut kriteria berikut: a. Metode garis lurus (straight line methtod).

Metode ini adalah depresiasi yang paling sederhana dan banyak digunakan. Dalam cara ini, beban depresiasi tiap periodenya jumlahnya sama. Besarnya depresiasi yang konstan setiap periode seolah-olah menunjukan bahwa kemampuan aktiva tetap relatif sama dalam suatu periode.

b. Metode saldo menurun (diminishing balance method).

Metode jumlah menurun ini akan menghasilkan beban penyusutan yang menurun setiap periode. Metode ini beranggapan bahwa akiva baru sangat besar perannya dalam usaha mendapatkan penghasilan, peranan aktiva tersebut semakin lama semakin megecil seiring dengan semakin tuanya aktiva tersebut. Tarif pajak dalam metode ini ditentukan terlebih dahulu dan besarnya sama untuk setiap tahun. Penyusutan dihitung dengan mengalihkan tarif dengan nilai buku yang semakin kecil.

c. 'Metode jumlah unit (Sum of the unit method).

Dalam metode ini umur kegunaan/masa manfaat aktiva tetap ditafsirkan dalam satuan jumlah unit hasil produksi. Beban penyusutan dihitung dengan dasar satuan hasil produksi, sehingga penyusutan tiap periode akan berfluktuasi sesuai dengan fluktuasi dalan hasil produksi. Dasar teori yang dipakai adalah suatu aktiva itu dimiliki untuk menghasilkan produk, sehingga depresiasi juga didasarkan pada jumlah produk yang dapat dihasilkan.

\subsection{Penghentian dan Pelepasan Aktiva Tetap}

Berkaitan dengan penghentian dan pelepasan aktiva tetap, Pernyataan Standar Akuntansi Keuangan Nomor 16 Paragraf 67, (2015: 16.20) menyatakan bahwa jumlah tercatat suatu aktiva tetap dihentikan pengakuannya pada saat dilepas atau ketika tidak terdapat lagi manfaat ekonomi masa depan yang diharapkan dari penggunaan atau pelepasanya.

Penghentian atau pelepasan dapat dilakukan dengan cara:

1. Penjualan aktiva tetap

2. Berakhirnya masa manfat aktiva tetap

3. Pertukaran aktiva tetap

4. Hibah

\subsection{Pelaporan dan Pengungkapan Aktiva Tetap}

Dalam laporan keuangan, penyajian aktiva tatap akan terlihat dalam neraca. Neraca merupakan suatu daftar yang menggambarkan komposisi harta, kewajiban dan modal pada suatu periode tertentu. Aktiva tetap yang disajikan berdasarkan nilai perolehan aktiva tersebut dikurangi dengan akumulasi penyusutannya. Setiap jenis aktiva tetap seperti tanah, bangunan, inventais kantor dan lain sebagainya harus dinyatakan dalam neraca secara terpisah atau terinci dalam catatan atas laporan keuangan.

Laporan keuangan yang lengkap terdiri dari komponen-komponen berikut ini:

1. Neraca,

2. Laporan laba rugi, 
3. Laporan perubahan ekuitas,

4. Laporan arus kas, dan,

5. Catatan atas laporan keuangan.

PSAK Nomor 16 (2015: 16.22) menyatakan, Laporan Keuangan mengungkapkan, untuk setiap kelompok aktiva tetap:

1. Dasar pengukuran yang digunakan dalam menentukan jumlah tercatat bruto,

2. Metode penyusutan yang digunakan,

3. Umur manfaat atau tarif penyusutan yang digunakan,

4. Jumlah tercatat bruto dan akumulasi penyusutan (jumlahkan dengan akumulasi rugi penurunan nilai) pada awal dan akhir periode, dan

5. Rekonsiliasi jumlah tercatat pada awal dan akhir periode.

Diketahiu bahwa aktiva tetap disajikan dalam laporan keuangan sebesar nilai buku saja dan kurangi dengaan akumulasi penyusutan pengungkapan aktiva tetap untuk lebih jelas disajikan dalam catatan atas laporan keuangan.

\subsection{Penelitian Terdahulu}

1. Penelitian yang dilakukan Ratag (2013) hasil penelitiannya menunjukkan bahwa PT. Bank Sulut telah sesuai dengan PSAK No. 16

2. Penelitian yang dilakukan Pricilia Veronika Timban (2016) hasil penelitiannya menunjukan bahwa PT. Massindo Sinar Pratama Manado telah sesuai dengan PSAK No. 16

3. Penelitian yang dilakukan Putra Kirana (2013) Hasil penelitian menunjukkan bahwa kebijakan perusahaan dalam perlakuan akuntansi aset tetap masih belum sesuai dengan PSAK No. 16

\section{METODE PENELITIAN}

\subsection{Jenis dan Sumber Data}

Sumber data dalam penelitian ini, adalah data primer dan sekunder.

1. Data Primer

Data primer adalah data dalam bentuk verbal atau kata-kata yang diucapkan secara lisan, gerak-gerak atau perilaku yang dilakukan oleh subjek yang dapat dipercaya, dalam hal ini adalah subjek penelitian yang berkenaan dengan variabel yang diteliti. Data yang diperoleh dari perusahaan dalam bentuk data mentah atau belum diolah dengan cara interakasi lisan atau keterangan langsung dari pihak accounting PT. Astra Sedaya Finance Manado.

2. Data Sekunder

Data sekunder adalah data yang diperoleh dari dokumen-dokumen grafis (tabel, catatan, notulen, rapat, dan lain-lain), foto-foto, rekaman vidio, benda-benda dan lain-lain yang dapat memperkaya data primer. Data yang diperoleh dari perusahaan dalam bentuk yang sudah jadi berupa daftar laporan keuangan, daftar aktiva tetap, sejarah singkat berdirinya perusahaan serta struktur organisasi perusahaan

Sumber data yang digunakan merupakan gabungan antara data primer dan sekunder yaitu berupa wawancara langsung dengan pimpinan perusahaan, bagian acoouunting, dan melalui buku-buku akuntansi

\subsection{Metode Analisis Data}

Metode analisis data yang dilakukan dalam penelitian ini adalah metode deskriptif, yaitu untuk mengambarkan secara sistematis, factual mengenai perlakuan akuntansi aktiva tetap pada PT. Astra Sedaya Finance dengan membandingkan perlakuan akuntansi sesuai dengan PSAK (Peryataan Standar Akuntansi Keuangan) No. 16 Tahun 2015 yang menyatakan bahwa "aktiva tetap disajikan berdasarkan nilai perolehan aktiva tersebut dikurangi dengan akumulasi penyusutan" 


\section{HASIL ANALISIS DAN PEMBAHASAN}

\subsection{Hasil Penelitian}

\subsubsection{Pengakuan Harga Perolehan Aktiva Tetap PT. Astra Sedaya Finance Manado}

Dalam kebijakan mengenai perlakuan akuntansi aktiva tetap PT. Astra Sedaya Financemempunyai berbagai jenis aset tetap yang di ikutsertakan dalam kegiatan operasional perusahaan. Kebijakan tersebut di dasarkan atas kebijakan pimpinan perusahaan, yang terdiri dari kendaraan roda 4 dan invenstaris kantor. PT. Astra Sedaya Finance mengklasifikasikan berdasarkan umur ekonomis dari masing-masing aset. Manajemen perusahaan telah menggolongkan setiap aset tetap yang ada dalam beberapa fungsi. Berikut ini di ambil dari 6 (enam) transaksi yang terdiri dari kendaraan roda 4 (empat), dan inventaris kantor.

Tabel 4.1. Daftar Aktiva Tetap PT. Astra Sedaya Finance 2015

\begin{tabular}{|c|c|c|c|c|c|c|}
\hline Nama & $\begin{array}{c}\text { Tanggal } \\
\text { perolehan }\end{array}$ & $\begin{array}{c}\text { Jlh } \\
\text { Unit }\end{array}$ & $\begin{array}{c}\text { Harga } \\
\text { perolehan }\end{array}$ & $\begin{array}{c}\text { Sisa masa } \\
\text { manfaat }\end{array}$ & $\begin{array}{c}\text { Tarif } \\
\text { Penyusutan } \\
\%\end{array}$ & $\begin{array}{c}\text { Biaya } \\
\text { Penyusutan } \\
\text { (Rp) }\end{array}$ \\
\hline $\begin{array}{c}\text { Mesin } \\
\text { Fotocopy fs } \\
1135 \mathrm{mfp}\end{array}$ & $30 / 10 / 15$ & 1 & 10.800 .000 & 7 & $12,5 \%$ & 1.350 .000 \\
\hline Computer & $27 / 11 / 15$ & 1 & 4.100 .000 & 7 & $12,5 \%$ & 512.500 \\
\hline $\begin{array}{c}\text { UPS Vektor } \\
\text { Alto 1200 }\end{array}$ & $25 / 05 / 15$ & 4 & 4.300 .000 & 7 & $12,5 \%$ & 537.500 \\
\hline $\begin{array}{c}\text { Filing Cabinet } \\
\text { 4 Laci }\end{array}$ & $28 / 11 / 15$ & 2 & 4.450 .000 & 7 & $12,5 \%$ & 556.250 \\
\hline $\begin{array}{c}\text { Handpone } \\
\text { Samsung }\end{array}$ & $15 / 08 / 15$ & 3 & 3.500 .000 & 7 & $12,5 \%$ & 437.500 \\
\hline $\begin{array}{c}\text { Mobil Pick Up } \\
\text { Grand Max }\end{array}$ & $26 / 10 / 15$ & 1 & 98.500 .000 & 8 & $12,5 \%$ & 12.312 .500 \\
\hline
\end{tabular}

\subsubsection{Pengukuran jumlah yang harus di catat atas Aktiva Tetap PT. Astra Sedaya Finance Manado.}

Pengukuran jumlah yang harus di catat atas aktiva tetap,pihak manajemen perusahaan menggunakan metode biaya historis (historical cost), aset tetap dicatat pada perolehan dikurangi akumulasi penyusutan. Pihak manajemen perusahaan tidak perna melakukan pengukuran/pengujian terhadap seluruh aktiva tetap pada setiap tanggal neraca (minimal setahun sekali di lakukan pemeriksaan), baik kendaraan roda 4 dan inventaris kantor, apakah aktiva tetap tersebut mengalami penurunan atau tidak, dengan menaksir jumlah yang dapat diperoleh kembali dari aset tersebut. Hal tersebut dapat dilihat dari 6 (enam) transaksi aktiva tetatap yang di beli dari tahun 2010 s/d 2015 yang tidak pernah di lakukan pengukuran penurunan nilai aset.

\subsubsection{Penyusutan Aktiva Tetap PT. Astra Sedaya Finance}

Sesuai dengan kebijakan manajemen perusahaan, metode yang digunakan untuk aktiva tetap, baik kendaraan roda 4 maupun inventaris kantor menggunakan garis lurus (straight line method) dengn tariff penyusutan sebagai berikut :

1. Kendaraan mobil : $12,5 \%$ dengan masa manfaat 8 tahun

2. Inventaris kantor : $12,5 \%$ dengan masa manfaat 8 tahun

Metode garis lurus didasarkan atas pertimbangan dan alasan yang layak, serta penerapan aktiva tetap yang dimiliki dalam konsisten. Sekalipun pihak manajemen perusahaan sudah memilih metode yang dianggap layak tetapi kalau pengakuan nilai perolehan suatu aktiva tidak sesuai dengan PSAK, maka perhitungan untuk biaya penyusutan dapat mengakibatkan selisih. Hal tersebut terjadi pada PT. Astra Sedaya Finance Manado 
ada beberapa pencatatan untuk nilai perolehan sesuai dengan PSAK dan ada juga yang tidak sesuai dengan PSAK.

Penentuan besarya harga perolehan aktiva tetap yang kurang tepat akan berpengaruh terhadap laporan keuangan yang disusun oleh perusahaan. Harga perolehan aktiva tetap menjadi lebih rendah dari yang disebabkan pada setiap periode akuntansi akan menjadi lebih rendah dari yang semestinya, sedangkan biaya-biaya ini akan menyebabkan biaya operasional dalam laporan aktivitas tersebut menjadi lebih rendah dari yang semestinyah. Penentuan beben operasi yang kurang tepat nilainya akan berpengaruh pula terhadap laba-rugi aktivitas yang diperoleh perusahaan.

\subsubsection{Penghentian Aktiva Tetap PT. Astra Sedaya Finance Manado}

Penghentian aset tetap dari penggunaan oleh PT. Astra Sedaya Finance dari tahun 2008 s/d 2015 didapati bahwa pihak manajemen perusahaan tidak pernah melakukan penghentian aset tetap. Hal tersebut di lihat dari pengambilan sampel untuk 6 (enam) transaksi dari daftar aktiva tetap dari tahun $2008 \mathrm{~s} / \mathrm{d} 2015$, terdapat beberapa aset tetap yang umur ekonomisnya telah habis (nilai perolehan telah habis di susutkan), dan sudah tidak dapat di gunakan lagi, tetapi masi ada di dalam daftar aktiva tetap perusahaan.

Pelaporan dan Pengungkapan Aktiva Tetap PT. Astra Sedaya Finance Manado untuk setiap pencatatan pada PT. Astra Sedaya Finance Manado yang berhubungan dengan aktiva tetap di sajikan dalam laporan neraca perusahaan serta laporan rugi laba. Hal tersebut dapat dilihat dari beberapa transaksi-transaksi yang berhubungan dengan aset tetap yang di ungkapkan di dalam laporan keuangan yaitu :

1. Pengakuan harga peroleh aset tetap

2. Metode penyusutan yang digunakan adalah metode penyusutan garis lurus dengan tarif penyusutan roda 4 (empat) sebesar 12,5\% dengan masa manfaat 8 tahun, serta untuk inventaris kantor sebesar $12.5 \%$.dengan masa manfaat 8 tahun

3. Pengakuan biaya penyusutan dibebankan langsung kelaporan laba rugi dengan mendebet akun biaya penyusutan

4. Pengakuan akumulasi penyusutan yang di catat pada akir periode dengan mengurangi harga perolehan pada neraca perusahaan.

5. Pengakuan penurunan nilai aset tidak di ungkapkan di dalam laporan keuangan, karena pihak manajemen perusahaan tidak pernah melakukan pemeriksaan setahun sekali terhadap aset tetapnya.

6. Penghentian aktiva tetap, tidak di ungkapakan dalam laporan keuangan, karena pihak manajemen perusahaan tidak pernah melakukan penghapusan aset tetap, sekalipun aset tersebut masa manfaatnya suda habis.

\subsection{Pembahasan}

\subsubsection{Pengakuan Harga Perolehan Aktiva Tetap PT. Astra Sedaya Finance Manado}

Bedasarkan data yang bersumber dari PT. Astra Sedaya Finance Manado perusahaan memperoleh aktiva tetap dengan cara pembelian tunai. Dari data yang ada mengenani perhitungan penentuan bersarnya harga perolehan aktiva tetap, terutama yang di ambil 6 (enam) contoh transaksi yang terjadi selama tahun 2015 terdapat ketidak tepatan dalam menentukan besarnya harga perolehan aktiva tetap. Hal ini jelas terlihat dalam mengkapitalisasi biaya-biaya untuk menentukan besarnya harga perolehan aktiva tetap dimana harga perolehanya tidak hanya berasal dari harga beli saja, tetapi ditambah biaya yang terjadi dalam rangka menepatkan aktiva tetap tersebut pada kondisi dan tempat, sehingga siap untuk di gunakan.

\subsubsection{Pengukuran jumlah yang harus di catat atas Aktiva Tetap PT. Astra Sedaya Finance Manado}

Menurut PSAK (Peryataan Standar Akuntansi Keuangan) No. 482015 meliputi :

1. Penurunan signifikan nilai pasar 
2. Peninkatan suku bunga pasar atau tingkat imbalan pasar inventasi

3. Jumlah tercatat aset neto entitas melebihi kapitalisasi pasarya

4. Bukti keusangan atau kerusakan fisik aset

Jika terdapat indikasi penurunan nilai seperti yang telah dijelaskan di atas, maka entitas harus melakukan uji penurunan nilai dengan cara membandingkan nilai tercatat aset dengan nilai terpulihkanya (nilai wajar). Berdasarkan data yang penulis peroleh dapat dilihat bahwa PT. Astra Sedaya Finance belum melakukan pengujian penurunan aset sesuai PSAK No. 16 . Hal tersebut dapat dilihat dari nilai buku masing-masing aset yang di beli dari tahun 2010 yang masi memiliki masa manfaat sampai dengan tahun 2015. Pihak manajemen perusahaan seharusnya setiap tahun melakukan pengujian terhadap penurunan nilai aset (membandingkan apakah nilai aset yang dicatat lebih besarlkecil dari nilai yang ada di pasaran)

\subsubsection{Penyusutan Aktiva Tetap PT. Astra Sedaya Finance}

Berdasarkan hasil dan data yang ditemui di perusahaan PT. Astra Sedaya Finance. Untuk penentuan besarya harga perolehan aktiva tetap yang kurang tepat akan berpengaruh terhadap laporan keuangan yang disusun oleh perusahaan. Harga perolehan aktiva tetap menjadi lebih rendah dari yang disebabkan pada setiap periode akuntansi dari yang semestinya, sedangkan biaya-biaya ini akan menyebabkan biaya operasional dalam laporan aktivitas tersebut menjadi lebih rendah dari yang semestinyah. Penentuan beben operasi yang kurang tepat nilainya akan berpengaruh pula terhadap laba-rugi aktivitas yang diperoleh perusahaan.

\subsubsection{Penghentian Aktiva Tetap PT. Astra Sedaya Finance Manado}

Berdasarkan penelitian yang dilakukan untuk penghentian aset tetap dari penggunanya oleh PT. Astra Sedaya Finance dari tahun 2010 s/d 2015 didapati bahwa pihak manajemen perusahaan tidak pernah melakukan penghentian aset tetap.

Menurut PSAK No. 16 tahun 20015 tetang penghentian aset bahwa ;

1. Jumlah tercatat aset tetap di hentikan pengakua pada saat :

a. di lepas; atau

b. telah habis umur ekonomisnya (nilai perolehanya telah habis disusutkan)

c. mengalami keusangan kemajuan teknologi

2. laba atau rugi yang timbul dari penghentian pengakuan aset tetap harus di masukan dalam laporan laba rugi pada saat aset tersebut dihentikan pengakuanya (kecuali transaksi jual sewa balik)

3. laba tidak boleh di klasifikasikan sebagai pendapatan

\subsubsection{Laporan dan Pengungkapan Aktiva Tetap PT. Astra Sedaya Finance Manado}

Berdasarkan penelitan yang penulis lakukan pada PT. Astra Sedaya Finance Manado untuk setiap pencatatan yang berhubungan dengan aktiva tetap di sajikan dalam laporan neraca perusahaan serta laporan rugi laba. Dari informasi penulis dapati untuk point $\mathrm{nmr} 1$ perlu ada penyeragaman harga didalam penentuan harga perolehan, karena ada beberapa transaksi-transaksi yang berhubungan dengan aset tetap, harga perolehanya suda sesuai dengan PSAK, tetapi ada juga yang tidak sesuai dengan PSAK, kemudian untuk point 2 sampai 4 sudah sesuai dengan PSAK, tentang penggunaan metode penyusutan serta pencatatan biaya penyusutan yang dibebankan langsung kelaporan laba rugi serta pencatatan akumulasi penyusutan yang mengurangi harga perolehan aset di neraca perusahaan, sedangkan untuk point nomor 5 dan 6 tidak sesuai dengan PSAK 48 Tahun 2015 tetang penurunan nilai aset dan PSAK No. 16 tahun 2015 tentang penghentian aset tetap bahwa; pihak manajemen perusahaan belum sepenuhnya melakukan penilaian dan penghentian terhadap aset tetap, apakah aset tetap yang digunakan oleh perusahaan masih memiliki nilai yang wajar di bandingkan dengan harga yang terjadi pada saat itu, serta kurangnya control 
dari pihak manajemen perusahaan tentang masa manfaat dari aset tetap apakah masi bisa digunakan atau tidak.

\section{KESIMPULAN DAN SARAN}

\subsection{Kesimpulan}

Berdasarkan hasil penelitian dan analisa yang di lakukan tentang perlakuan akuntansi aktiva tetap pada PT. Astra Seaya Finance Manado maka penulis menyimpulkan :

1. Untuk Pengakuan Harga Perolehan Aktiva Tetap PT. Astra Sedaya Finance Manado teryata didapati ada beberapa point yang belum sesuai. Yaitu pada saat perolehan aktiva tetap, untuk harga perolehan PT. Astra Sedaya Finance Manado hanya dicatat sebesar harga beli sedangkan biaya-biaya yang di keluarkan sehubungan dengan perolehan aktiva tersebet diangap sebagai biaya operasional, sekalipun tidak semua trasaksi-transaksi yang berhubungan dengan aktiva tetap di catat hanya sebesar harga beli, ada juga aktiva tetap yang catat sesuai dengan harga perolehanya (sudah termasuk harga beli, biaya pengiriman, asuransi dan pajak). Terdapat perbedaan yang cukup mendasar antara laporan keuangan perusahaan dengan analisis penulis yaitu dalam perhitungan daftar aktiva tetap yang di buat oleh PT. Astra Sedaya Finance dan Penulis yaitu sebesar Rp. 250.750,- pada harga perolehan mesin fotocopy dan penyusutanyah sebesar Rp. 31.344,- untuk ups vector 4 (empat) unit sebesar Rp. 750.350,- pada harga perolehan dan Rp. 93.794,- untuk penyusutannya sedangkan untuk pembelian komputer dan filling cabinet serta kendaraan roda 4 tidak terjadi selisi perbedaan harga perolehan. Hal ini terjadi karna PT. Astra Sedaya Finance Manado mencatat aktiva tetap dengan mencantumkan harga beli tampa menambahkan biaya yang diperlukan untuk memperoleh aktiva tetap sebagai harga perolehan. Aktibatnya biaya penyusutan aktiva tetap pada PT. Astra Sedaya Finance Manado menjadi lebih kecil dari yang seharusya.

2. Pengukuran Jumlah Yang Harus Dicatat Atas Aktiva Tetap PT. Astra Sedaya Finance. Berdasarkan data yang penulis peroleh dapat dilihat bahwa PT. Astra Sedaya Finance belum melakukan pengujian penurunan aset sesuai PSAK No. 16. Hal tersebut dapat dilihat dari nilai buku masing-masing aset yang di beli dari tahun 2010 yang masi memiliki masa manfaat sampai dengan tahun 2015. Pihak manajemen perusahaan seharusnya setiap tahun melakukan pengujian terhadap penurunan nilai aset (membandingkan apakah nilai aset yang dicatat lebih besarkkecil dari nilai yang ada di pasaran)

3. Berdasarkan hasil dan data yang ditemui di perusahaan. Untuk Penyusutan Aktiva Tetap PT. Astra Sedaya Finance Manado. Metode yang digunakan yaitu Metode Garis Lurus didasarkan atas pertimbangan dan alasan yang layak, serta penerapan aktiva tetap yang dimiliki dalam konsisten. Sekalipun pihak manajemen perusahaan sudah memilih metode yang dianggap layak tetapi kalau pengakuan nilai perolehan suatu aktiva tidak sesuai dengan PSAK, maka perhitungan untuk biaya penyusutan dapat mengakibatkan selisih. Hal tersebut terjadi pada PT. Astra Sedaya Finance Manado ada beberapa pencatatan untuk nilai perolehan sesuai dengan PSAK dan ada juga yang tidak sesuai dengan PSAK yaitu antara lain: Untuk perhitungan Mesin Fotocopy $1135 \mathrm{mfp}$ Perhitungan penyusutan yang dilakukan perusahaan tidak tepat karna perusahaan menentukan harga perolehan sebesar harga beli yang Rp. 10.800.000,sedangkan menurut PSAK sebesar Rp. 11.050 .750 yaitu harga beli sebesar Rp. 10.800.000 di tambah biaya pengiriman yang di keluarkan sebesar Rp. 250.750. Selanjutnya Untuk pencatatan pada tanggal 22 mei 2012 PT. Astras Sedaya Finance memebeli ups veckor alto 1200 yang di beli 4 (unit) Perhitungan penyusutan yang dilakukan perusahaan tidak tepat karena perusahaan menentukan harga perolehan 
sebesar harga beli yaitu Rp. 4.300.000,- sedangkan menurut PSAK sebesar Rp. 5.050.350 yaitu harga beli sebesar Rp. 4.300.000,- di tambah dengan biaya pengiriman yang di keluarkan sebesar Rp. 750.350 .

4. Penghentian Aktiva Tetap pada PT. Asrtra Sedaya Finance Manado mengenai penghentian aktiva tetap, tidak pernah dilakukan oleh pihak manajemen perusahaan, apakah aktiva tetap trersebut sudah mengalami penurunan nilai dengan nilai buku dan nilai wajar serta penggunaan aktiva tetap yang sudah habis umur ekonomisnya (20101015), apakah akan di lakukan penghentian aktiva tetap dengan mendebet akun akumulasi penyusutan dan mengkredit akun aktiva tetap. Hal tersebut akan mempengaruhi penyajian laporan keuangan perusahaan.

5. Pelaporan Dan Pengungkapan Aktiva Tetap pada PT. Astra Sedaya Finance Manado. Untuk setiap pencatatan yang berhubungan dengan aktiva tetap di sajikan dalam laporan neraca perusahaan serta laporan rugi laba. Dari informasi penulis dapati untuk point $\mathrm{nmr} 1$ perlu ada penyeragaman harga didalam penentuan harga perolehan, karena ada beberapa transaksi-transaksi yang berhubungan dengan aset tetap, harga perolehanya suda sesuai dengan PSAK, tetapi ada juga yang tidak sesuai dengan PSAK, kemudian untuk point 2 sampai 4 sudah sesuai dengan PSAK, tentang penggunaan metode penyusutan serta pencatatan biaya penyusutan yang dibebankan langsung kelaporan laba rugi serta pencatatan akumulasi penyusutan yang mengurangi harga perolehan aset di neraca perusahaan, sedangkan untuk point nomor 5 dan 6 tidak sesuai dengan PSAK 48 Tahun 2015 tetang penurunan nilai aset dan PSAK No. 16 tahun 2015 tentang penghentian aset tetap bahwa; pihak manajemen perusahaan belum sepenuhnya melakukan penilaian dan penghentian terhadap aset tetap, apakah aset tetap yang digunakan oleh perusahaan masih memiliki nilai yang wajar di bandingkan dengan harga yang terjadi pada saat itu, serta kurangnya control dari pihak manajemen perusahaan tentang masa manfaat dari aset tetap apakah masi bisa digunakan atau tidak. Perlakuan akuntansi aktiva tetap sangat berpengaruh terhadap laporan keuangan. Perlakuan akuntansi pada saat perolehan dan pengunaan aktiva tetap yang tidak sesuai dengan PSAK (Peryataan Standar Akuntansi Keuangan) menyebabkan nilai aktiva tetap yang di laporkan pada laporan keuangan tidak sesuai. Hal ini juga mempengaruhi juga biaya operasional dan jumlah laba yang terdapat pada laporan keuangan suatu perusahaan.

\subsection{Saran}

Berdasarkan hasil pembahasan dengan melihat kondisi perusahaan, maka penulis menyarankan perlu adanya penyeragaman yang harus dilakukan oleh pihak manajemen perusahaan agar pencatatan harga perolehan aktiva sesuai dengan PSAK (Peryataan Standar Akuntansi Keuangan). Untuk Perlakuan Akuntansi Aktiva Tetap pada PT. Astra Sedaya Finance Manado, perlu adanyan internal control yang baik, di mulai dengan penetapan harga perolehan untuk suatu aktiva yang di beli, supaya terjadi penyeragaman didalam pencatatan nilai perolehan, serta perlu di lakukan pemeriksaan daftar aktiva tetap (satu tahun sekali) yang di buat dengan membandingkan jumblah fisik aktiva tetap yang ada diperusahaan, sehingga dapat di ketahui aktiva tetap yang mana, yang sudah mengalami penurunan nilai yang sudah tidak sesuai dengan harga pasar (nilai wajar) serta aktiva tetap yang mana yang umur ekonomisnya sudah habis dan sudah tidak bisa di gunakan (sudah rusak), agar dilakukan penghapusan aktiva tetap dengan mendebet akun akumulasi penyusutan dan mengkredit akun aktiva tetap. Dengan demikian penyajian di dalam laporan keuangan dapat menunjukan nilai yang sebenarnya dari aktiva tetap tersebut. 


\section{DAFTAR PUSTAKA}

Albertus. 2013. Prinsip-prinsip dasar akuntansi. Dunia Cerdas. Jakarta

Harahap, Sofyan. 2013 Analisis Kritis Atas Laporan Keuangan. Penerbit Rajawali Pers. Jakarta Wild. J.J.,K.W. Shaw, B.Chiapetta, dan W.Work, 2014 Financial Accounting, $2^{\text {nd }}$ ed.,Amerika Serikat : Mc Graw-Hill Education.

Pontoh, Winston. 2013. Akuntansi Konsep dan Praktik. Penerbitan Halaman Moeka. Jakarta Barat. Hery. 2012. Akuntansi Keuangan Menengah. Jakarta: Bumi Askara

Kasmir, 2013. Analisis Laporan Keuangan. Rajawali Pers, Jakarta Munawir, 2012. Analisi Laporan Keuangan. Yogyakarta: Liberty

Hanafi, 2012, Analisis Laporan Keuangan. Yogyakarta: (UPP) STIM YKPN

Surya, Raja AdriSatriawan, 2012 Akuntansi Keuangan IFRS. Edisi Pertama. Penerbit Graha Ilmu, Yogyakarta.

Reeve, James M, Carl S. Waren dan Jonathan E. Duchac. Pengantar Akuntansi Adpatasi Indonesia Buku 2. Penerbit Salemba Empat, Jakarta.

Epi. 2013. Akuntansi Gampang, Dunia Cerdas. Jakarta.Graha Ilmu, Yogyakarta.

Ratag, Suryani Miyoko, 2013. Perlakuan Akuntansi Capital Expenditure Dan Revenue Expenditure Pada PT. Bank SULUT. Universitas Sam Ratulangi Manado. Jurnal EMBA ISS 2303-1174. Vol. 3.

Kaopaha,Veronika. 2014. Evaluasi Penerapan Perlakuan Akuntansi Aktiva Tetap Berdasarkan Psak No.16 pada Rsup Prof.Dr.R.D. Kandou Manado. Jurnal Emba. Vol.2 No.3 September 2014. Hal.218-226. Fakultas Ekonomi, Universitas Sam Ratulangi.Manado.

Hery. 2012. Akuntansi Keuangan Menengah. Jakarta: Bumi Askara

Ikatan Akuntan Indonesia ,2015. Standar Akuntansi Keuangan. Salemba Empat, Jakarta.

Kirana, Putra. 2013. Perlakuan Akuntansi Aset Tetap Berdasarkan PSAK No.16 pada PT.Graphika Beton. Jurnal. Falkutas Ekonomi. Universitas Maritim Raja Ali Baji, Tanjungpinang. 